\title{
Durability of operated reinforced concrete superstructures of railroad bridges
}

\author{
Stefan Efimov ${ }^{1, *}$, Sergey Bokarev ${ }^{1}$, and Sergey Pribytkov ${ }^{1}$ \\ ${ }^{1}$ Siberian Transport University, 630049 Novosibirsk, Russia
}

\begin{abstract}
The paper describes method to evaluate residual service life of reinforced concrete structures of railroad bridges, enabling to consider the presence of defects, operation history, and climatic factor to calculate probabilities of the structural state at any given moment of time. The model based on semi-Markov process was used to predict the state and calculate reliability indicators of structures and their elements. The data sources for reliability models are results of observations of the structural state, mathematical models of occurrence and development of defects. The example of determining residual service life of reinforced concrete superstructure is given based on the mathematical model of working reinforcement corrosion development.
\end{abstract}

\section{Introduction}

Over forty three thousand reinforced concrete superstructures are currently being operated on the railway network in the territory of the Russian Federation [1,2]. The major part is slab and ribbed structures which are mainly produced from conventional reinforced concrete and designed to sustain the loads of 1907, 1925, H7, H8, C14, etc. The range of the covered spans is from 1.3 to $16.5 \mathrm{~m}$. The service life of $4.6 \%$ of superstructures, designed by the projects of 1911 to sustain the load of 1907 is $>90-100$ years. Superstructures designed to sustain the load of 1925 (2.6\% of the total superstructures amount) are being under operation for 80-90 years, withstanding the load $\mathrm{H7}$ (6.1\%) and H8 $(29.3 \%)$ - for $70-85$ years. The service life of superstructures designed to sustain the load $\mathrm{C} 14$ (54.1\%) does not exceed 50 years.

Apart from constant and temporary loads acting on reinforced concrete superstructures while operation they are also subjected to external environmental impacts, which generally have negative influence on reinforced concrete reducing its operation properties. Technical condition of the basic load bearing structures is generally determined by their service life, design features and operation conditions. According to the database of Automated Control System of Engineering Structures the relative number of superstructures on the network of "Russian Railways" JSC, having the following defects reducing the durability and load bearing capacity is as follows: the ballast depth under the tie above the admitted value $20.9 \%$; alkali washing of hardened cement paste $-20.1 \%$; eccentricity of the railway over $5 \mathrm{~cm}-19.6 \%$; frost deterioration of concrete $-7.9 \%$; delamination of reinforcement

\footnotetext{
* Corresponding author: esv@sgups.net
} 
protective layer $-6.2 \%$; longitudinal sidewall extended by over $20 \mathrm{~cm}-4.8 \%$; reinforcement corrosion $-2.4 \%$; cracks along the rods of working reinforcement $-2.0 \%$.

Considering the above data it can be noticed that the largest number of defects in maintenance of bridge deck is caused by such out-of-tolerance deviations [3] as ballast thickness layer and eccentricity of the railway. The next is negative water influence, as well as alternate freezing and thawing of concrete resulting in alkali washing and frost deterioration.

\section{Materials and methods}

Determining the residual service life is a required procedure in bridge operation. Up to date, this problem is not solved yet in the world practice $[4,5]$ and there are various approaches and ways to determine the standard and residual service life of reinforced concrete superstructures.

Foremost it should be clarified what residual service life means. Russian National State Standard GOST 32192-2013 [6] states that residual service life is operation time which is determined at the present moment of time before its transition into the limit state. This standard also defines that the limit state is the state when further operation is not possible and inappropriate due to risk assessment. Technical Regulations on Safety of Buildings and Structures (Federal Law No. 384) defines the limit state as the state when further operation is dangerous, constrained or inappropriate or recovering of operation condition is impossible or inappropriate. Keeping these definitions in mind it can be concluded that the limit state can be defined as non-operating state (further operation is not allowed) and the state when the recovery is not possible or irrational. This research was centered upon the assessment of the value of operation time before transition into non-operating state. Possibility and appropriateness to recover service life are the issues to be investigated.

The method to determine the residual service life suggested in the present work is based on the following background:

1. Adherence to the approach implemented in Instruction on State Estimation (scoring of the condition upon presence of defects of the superstructure) [7].

2. Complete correspondence to the National State Standard GOST 32192-2013 "Reliability of railroad engineering. The basic notions, terms and definitions" [6].

3. Implementation of the concept of methodology on resource, risks and reliability management at all the stages of lifecycle.

Let us define the parameters of objects under study, i.e. reinforced concrete superstructures. They are given as complex systems containing multiple elements. Each of the elements has its purpose and structure; each of them is generally subjected to the action of several factors and can have several various defects. There is an approach for engineering systems which consists in the use of particular reliability indicators (failurefree operation, durability, load bearing capacity, repair capability). These indicators characterize the ability of superstructure to fulfill the required functions.

During operation resulting from damages caused by various natural environment, climatic and man-made impacts defects occur in superstructures. Their condition deteriorates up to their complete failure. Thus, variety of possible states (Fig. 1) of both element and the structure on the whole includes:

1. Properly operating (index 0) - there are no defects, efficient, without speed limitations, complete residual service life;

2. Defective operating - completely operating states, characterized by presence of defects with various degree of development and reduced residual service life;

- good (index 1) - defects with the least degree of development;

- satisfactory (index 2) - defects with “medium” degree of development; 
- unsatisfactory (index 3) - serious defects;

- pre-failure (index 4) - operating state with defects of maximum permissible degree of development, the residual service life is close to zero;

- when imposing speed limitation for the applied load or banning to pass separate types of rolling stock the object is considered as being in partly operating state (index 4.1);

3. Defective non-operating (index 5) - significant defects (up to destruction of load bearing structures), complete inability to fulfill its functions, the residual service life is over, moving is prohibited.

\begin{tabular}{|c|c|c|c|c|c|}
\hline \multicolumn{6}{|c|}{ Possible conditions } \\
\hline \multirow[t]{4}{*}{ Operating $\mathrm{S}_{0}$} & \multicolumn{5}{|c|}{ Defective } \\
\hline & \multicolumn{4}{|c|}{ Operating } & Failure $\mathrm{S}_{5}$ \\
\hline & Good $\mathrm{S}_{1}$ & Satisfactory $\mathrm{S}_{2}$ & $\begin{array}{l}\text { Unsatisfactory } \\
\mathrm{S}_{3}\end{array}$ & Pre-failure $\mathrm{S}_{4}$ & \\
\hline & & & & $\begin{array}{c}\text { Partially } \\
\text { operating } \mathrm{S}_{4.1}\end{array}$ & \\
\hline
\end{tabular}

Fig. 1. Hierarchy of multiple possible states of the structure.

The residual service life of the element in operating state is equal to the standard one. Defective states differ by the degree of defects development. Pre-failure state is characterized by the borderline, maximum allowable degree of defects development. The structure could turn from pre-failure state into non-operating one. In pre-failure state the residual service life of the structure is almost over.

Deterioration of condition takes place due to occurrence of damages and growth of defects. The process of changing the condition is accidental. The possibility of failure leading to undesirable effects is defined according to the reliability models. In order to predict the state and calculate the reliability indicators of structures and their elements the model based on semi-Markov process is used.

The state model presented as semi-Markov process is set by distribution function matrix given in Figure 2. According to the model the probability of each of the possible states is determined at any pre-set moment of time.

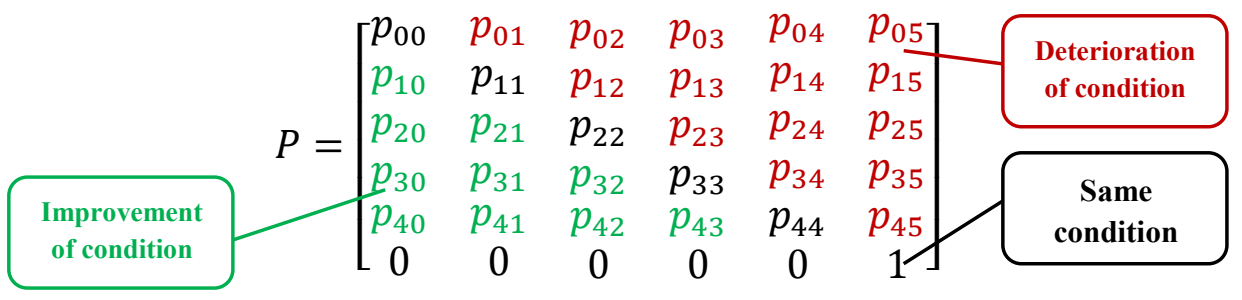

Fig. 2. Transition probability matrix.

The data sources to build the reliability model can be results of observations from the database of Automated Control System of Engineering Structures (the observations mean inspections, surveying, testing and results of load bearing capacity calculations), mathematical models of occurrence and development of defects, as well as expert estimates. The preference should be given to statistics, as assessment based on the facts is 
better than experts' suppositions and theoretical conclusions. In case there is insufficient data on observations of the definite object, one needs to generalize observations of all the other objects similar to it. Provided that this data is also insufficient, one should appeal to mathematical models, and in the last turn to the experts' assessments. The calculation can determine the probability of failure during the pre-set time, the average time before failure, g-percentage service life (time before reaching the limit state with the given probability).

\section{Results}

Density of probability distribution of reinforced concrete superstructure being in one state before transition into the other state is complying with the distribution law of VeibullGnedenko with two parameters $[8,9,10]$. Probability density function looks as follows:

$$
f(t)=\frac{\beta}{\eta}\left(\frac{t}{\eta}\right)^{\beta-1} e^{-\left(\frac{t}{\eta}\right)^{\beta}}
$$

where $\beta$ is shape parameter;

$\eta$ - scale parameter ("typical” service life).

The graphs of several of these functions $f(t)$, based on the statistical data processing of observing the state of reinforced concrete superstructures on the West Siberian railway according to database Automated Control System of Engineering Structures are given in Figure 3. It is rational to build these graphs for various roads or regions or to use climatic coefficient $k_{c}$.

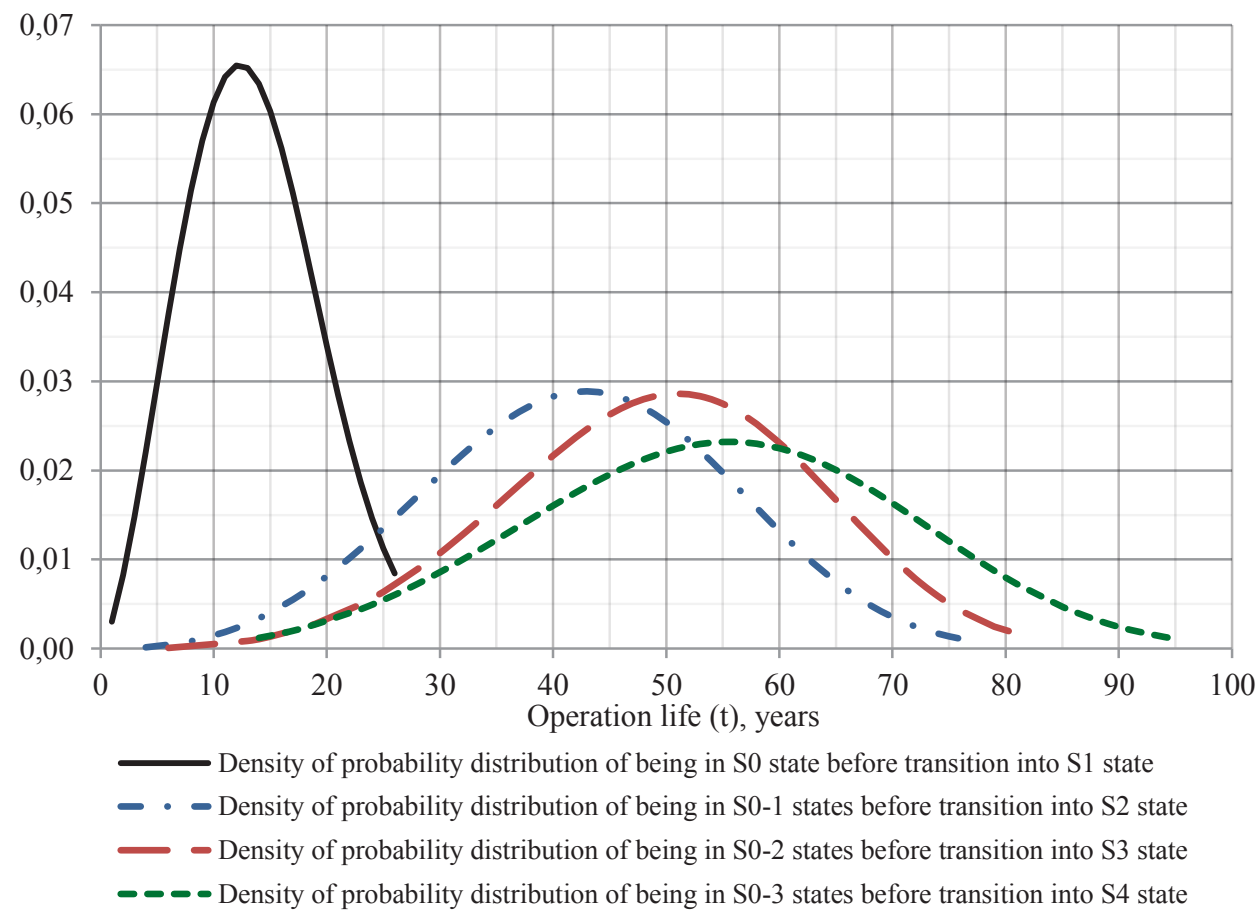

Fig. 3. Density of probability distribution of being in one state before transition into the other.

Let us consider the residual service life in details on the example of mathematical model of reinforcement corrosion development. 
The time from the initiation of operation up to transition into $\mathrm{S}_{4}$ state is determined according to the following formula $[11,12,13]$ :

$$
T_{0-4}=k_{c}\left(T_{1}+T_{4}\right)
$$

Where $T_{1}$ is the duration of corrosion initiation period), $k_{c}$ - climatic coefficient, $T_{4}-$ time of corrosion development before the loss of reinforcing steel area reducing the load bearing capacity of the superstructure up to the level of applied loads (e.g. 10\% of total area):

$$
M_{\text {prel }}=M_{\text {load }}
$$

where $M_{\text {prel }}=f\left\{A_{s}(t)\right\}, M_{\text {load }}=f\{v(1+\mu)\}$.

In $\mathrm{S}_{4}$ state the pass of load is only possible when the speed or mass is limited, when following the condition of:

$$
M_{\text {prel }}>M_{\text {load }}
$$

The surface of reinforcement subjected to corrosion can be determined according to the following formula at any moment of time $[11,12,13]$ :

$$
A_{s}=A_{S, 0}\left(1-\frac{2}{d} C_{\ni} t^{m}\right)
$$

where $d$ is the diameter of working reinforcement, $\mathrm{mm} ; C_{\ni}-$ the velocity of reinforcement corrosion, within the interval of $0.08 \ldots 0.3 \mathrm{~mm} /$ year; $m$ - indicator of the corrosion degree, within the interval of $0.3 \ldots 0.5 ; t$ - time from corrosion initiation up to the current or predicted state; $A_{s, 0}$ - total reinforcement area not subjected to corrosion.

The condition of $10 \%$ loss of reinforcement surface area:

$$
\frac{2}{d} C_{\ni} T_{4}^{m} \geq 0,1
$$

Thus, the time from initiation of corrosion development up to $10 \%$ loss of reinforcement surface area can be determined as follows:

$$
T_{4}=\left(\frac{0,05 d}{C_{\ni}}\right)^{\frac{1}{m}}
$$

The time of transition from $\mathrm{S}_{0}$ state into $\mathrm{S}_{5}$ can be defined as:

$$
T_{0-5}=T_{1}+T_{5}
$$

where $T_{5}$ is the duration of corrosion development up to the loss of such reinforcement surface area when the ultimate force in the element will be equal to the force of train load not considering the dynamic coefficient $1+\mu=1,0$.

In $\mathrm{S}_{5}$ state pass of the load is impossible.

\section{Conclusion}

As has been noted, reinforced concrete superstructures on the railway network are operated in various climatic zones and are to various extend subjected to the influence of negative environmental impacts. All these peculiar features are to be considered when determining the service life of reinforced concrete superstructures. 
The suggested methods enable to account for the location region of reinforced concrete superstructure (e.g. by climatic coefficient), presence of existing defects (according to the acting Instruction [7] and Classifier [14]) and determine the probability of its state deterioration or failure. Based on the calculation, planning of the current maintenance is possible along with justification of the necessary repair works.

When conducting further studies it is necessary to take into account the economic feasibility of superstructures recovery with the aim of either their condition improvement or sustaining the current state of the structure up to its replacement. Apart from that, when calculating the residual service life of superstructures it is also required to account future planned reconstruction and repair works.

\section{References}

1. S.A. Bokarev, S.V. Efimov, Siberian Transport University Bulletin, 2, 10-20 (2016). (in Russian)

2. S.A. Bokarev, A.M. Karaulov, K.V. Korolev, S.V. Efimov, News of higher educational institutions. Construction, 4, 82-92 (2017). (in Russian)

3. CP-628. Instrukcija po soderzhaniju iskusstvennyh sooruzhenij [Instruction on the maintenance of artificial structures] (Ministry of Railways of Russian Federation, Moscow, 1998). (in Russian)

4. K. Gode, Construction science, Vol. 15, 11-18 (2014).

5. S. Rostam, Asian Journal of Civil Engineering (Building and Housing), Vol. 6, 15630854 (2005).

6. GOST 32192-2013. Dependability in railway technics. General concepts. Terms and definitions (Standartinform, Moscow, 2016). (in Russian)

7. Instrukcija po ocenke sostojanija i soderzhanija iskusstvennyh sooruzhenij na zheleznyh dorogah Rossijskoj Federacii [Instruction on the assessment of the state and content of artificial structures on the railways of the Russian Federation (OJSC "RZD”, Moscow, 2006). (in Russian)

8. B.R. Levin, Spravochnik po nadezhnosti [Reliability Guide] (Mir, Moscow, 1969). (in Russian)

9. Metodicheskie ukazanija po ocenke riskov iskusstvennyh sooruzhenij [Methodological instructions for the assessment of risks of artificial structures] (OJSC "RZD”, Moscow, 2018). (in Russian)

10. A.I. Orlov, Matematika sluchaja. Verojatnost' $i$ statistika - osnovnye fakty, [Probability and statistics - basic facts] (Moscow, 2004). (in Russian)

11. A.I. Vasilyev, Ocenka tehnicheskogo sostojanija mostovyh sooruzhenij [Assessment of technical condition of bridge structures] (Knorus, Moscow, 2017). (in Russian)

12. V.P. Chirkov, Osnovy teorii proektirovanija stroitel'nyh konstrukcij. Zhelezobetonnye konstrukcii [Fundamentals of the theory of building structures design. Reinforced concrete structures] (Moscow, 1999). (in Russian)

13. V.P. Chirkov, Prikladnye metody teorii nadezhnosti $v$ raschetah stroitel'nyh konstrukcij [Applied methods of reliability theory in calculations of building structures] (Marshrut, Moscow, 2006). (in Russian)

14. Klassifikator i normy porogovyh znachenij kriticheskih parametrov, harakterizujushhih predotkaznoe sostojanie iskusstvennyh sooruzhenij [Classifier and norms of threshold values of critical parameters characterizing the pre-failure state of artificial structures] (OJSC “RZD”, Moscow, 2017). (in Russian) 